\title{
Role of iron sucrose infusion in correction of iron deficiency anemia during pregnancy
}

\author{
Sanket V. Modh*, Kruti J. Deliwala, Parul T. Shah, Rina V. Patel
}

Department of Obstetrics and Gynecology, Sheth V.S. General Hospital, Ahmedabad, Gujarat, India

Received: 22 September 2015

Revised: 28 September 2015

Accepted: 29 September 2015

\section{*Correspondence:}

Dr. Sanket V. Modh,

E-mail: sanketmodh@gmail.com

Copyright: (c) the author(s), publisher and licensee Medip Academy. This is an open-access article distributed under the terms of the Creative Commons Attribution Non-Commercial License, which permits unrestricted non-commercial use, distribution, and reproduction in any medium, provided the original work is properly cited.

\begin{abstract}
Background: Iron deficiency anemia (IDA), is defined as decrease in the amount of red blood cells (RBCs) or hemoglobin in the blood due to insufficient iron in the body. We carried out this study to measure the efficacy of iron sucrose in iron deficiency anemia in pregnant women.

Methods: In our prospective study 100 patients were included. All of them were having USG maturity between 15-34 weeks. All of them were given iron sucrose IV according to their requirements and follow-up was taken after 4 weeks by measuring $\mathrm{Hb}$ level.

Results: Hb level improved significantly (2.1 grams) within a short duration of interval. $14 \%$ patients suffered from minor side effects.

Conclusions: Iron sucrose has been found very useful for correction of iron deficiency anemia in antenatal patients.
\end{abstract}

Keywords: Anemia in pregnancy, Iron deficiency anemia, Parenteral iron, Iron sucrose

\section{INTRODUCTION}

Iron deficiency anemia (IDA), is defined as decrease in the amount of red blood cells (RBCs) or hemoglobin in the blood due to insufficient iron in the body. ${ }^{1}$

Anemia is estimated to affect nearly two thirds of the pregnant women in developing countries. Iron deficiency anemia is responsible for $95 \%$ of the anemias during pregnancy. According to WHO, the prevalence of IDA is about $18 \%$ in developed countries and 35-75\% (average $56 \%$ ) in developing countries. ${ }^{2}$ Globally, the prevalence of anemia is $55.9 \%$ with variations between developed and developing countries. In India, prevalence ranges between 33-89 \%. ${ }^{3}$ About half of the global maternal deaths due to anemia occur in South Asian countries; India contributes to about $80 \%$ of this mortality ratio.
During 10th Five Year Plan (2002-2007), ${ }^{6}$ a study conducted by ICMR (Indian Council of Medical Research) ${ }^{6}$ showed that the prevalence of anaemia was highest among pregnant women (50-90\%) and that of moderate $(<8 \mathrm{~g} \mathrm{\%})$ and severe anemia $(<5 \mathrm{~g} \%)$ was persistently high. Prevalence was high in all States of the country with considerable variations in moderate to severe anemia. ${ }^{7}$ Other factors responsible for high incidence of anemia in our country include early marriage, teenage pregnancy, multiple pregnancies, less birth spacing, phytate rich Indian diet, low iron and folic acid intake and high incidence of worm infections in Indian population. ${ }^{8}$

WHO defines anemia as hemoglobin $(\mathrm{Hb})<11 \mathrm{~g} \% .^{2}$ In India, the ICMR classification of iron deficiency anemia is: 
- $\quad 8-11 \mathrm{~g} \mathrm{\%}$ : mild

- $\quad 5-8 \mathrm{~g} \%$ : moderate

- $\quad<5 \mathrm{~g} \%$ : severe

In absence of interfering factors, serum ferritin $<12-15$ $\mu \mathrm{g} / \mathrm{l}$ is considered as iron deficiency. ${ }^{5}$

IDA is the most common nutritional deficiency in pregnant women. The factors producing IDA generally precedes the pregnancy, including diet poor in iron content coupled with menstrual losses and a rapid succession of pregnancies in which supplemental iron was not provided. Most women begin their pregnancy with partially or completely depleted iron reserves. Thus, the severity of the anemia is inversely related to the amount of iron reserves. During pregnancy, there is a great demand for iron to meet the requirement of red blood cell mass expansion in the mother, fetal and placental blood and blood loss during delivery time. Iron deficiency is exaggerated because of the ability of fetus to extract its requirement. This is aggravated by poor absorption of iron due to adverse effects of pregnancy on the gastrointestinal tract, which include nausea and vomiting, motility disorder with reflux esophagitis and indigestion.

In underdeveloped countries, anemia is a major contributory factor to maternal morbidity and mortality. Inadequate antenatal care along with poor knowledge of dietary needs of pregnant woman, and poor socioeconomic conditions are responsible for this in our country. It is also associated with high perinatal mortality rate in our region. A recent study reported a fetal mortality rate of $50 \%$ at 5 month, $28 \%$ at 7 months and $24 \%$ at 9 months of gestation.

Over the past years, various oral, intramuscular and intravenous preparations of iron have been used for correction of IDA in the pregnant patients. However, they are associated with significant side effects and it is not possible to achieve the target rise in $\mathrm{Hb}$ level in a limited time-period when patient is approaching the term. Recently, iron sucrose complex (ISC) is a relatively new drug, which is used intravenously for the correction of IDA. Parenteral injections of iron-dextran /sorbitol complex have its own limitations and disadvantages. Blood transfusion is the last resort and can be used only in severe cases of anemia in symptomatic patients. ${ }^{9,10} \mathrm{On}$ the other hand, blood transfusion, although it can promptly and reliably treat anemia, entails a lot of dangers like cross reactions and viral infections. Considering the advantages and limitations of the available options, intravenous iron sucrose therapy is reported to be safe, convenient and more effective than I/M or I/V iron - dextran/sorbitol therapy in treatment of iron deficiency anaemia. ${ }^{11,12}$ ISC has been able to raise the $\mathrm{Hb}$ to satisfactory level when used in severely anemic iron deficient pregnant women. The aim of this study was to assess the efficacy and tolerability of ISC in pregnant patients with IDA seen at our institution.
Iron sucrose is a form of the mineral iron. Iron is important for many functions in the body, especially for the transport of oxygen in the blood. Iron sucrose injection is used to treat iron deficiency anemia and is usually given with another medication to promote the growth of red blood cells.

\section{Pharmacokinetics:}

- Half-life elimination: 6 hour

- Volume of distribution: 7.9-10 L

- Clearance: $1.2 \mathrm{~L} /$ hour

- Excretion: Urine (5\%)

\section{METHODS}

This was a prospective study in V.S. General Hospital, Ahmedabad, India during January to June 2015. We had included 100 patients in our study who were suffering from iron deficiency anemia ( $\mathrm{Hb}$ 6-8 gm \%). They all were given iron sucrose infusion according to their requirement.

$$
\begin{gathered}
\text { Requirement of iron }=2.3 \times[(12-p t \text { 's Hb }) \times \text { wt. }]+500 \\
\text { mg. }
\end{gathered}
$$

Iron sucrose infusion was given on alternate day. A single dose consisted of $200 \mathrm{mg}$ iron sucrose in $100 \mathrm{ml}$ normal saline.

\section{Exclusion criteria}

- Patients not willing to participate in the study

- Patients with history of hypersensitivity to iron preparations

- Pt having USG maturity <15 weeks or >34 weeks

- Pt having $\mathrm{Hb}<6$ gm or $>8$ gm

- Anemia resulting from other causes

- Patients with infection, nephritis, CRF, hemoglobinopathies and chronic bleeding due to any cause other than menstrual disorders

- Patients with any neoplastic condition or having other diseases (inclusive of cardiac failure, renal failure) along with anemia

Follow up was taken after 4 weeks, by measuring $\mathrm{Hb}$ level.

\section{RESULTS}

Thus in our study almost $50 \%$ of the patients were having their maturity between $26-30$ weeks.

Patients having least $\mathrm{Hb}$ level were amongst the lowest maturity group (15-20 weeks). 
This results conclude that the highest rise (after 4 weeks) in $\mathrm{Hb}$ level was seen among patients with 15-20 weeks maturity, followed by early third trimester (31-34 weeks).

Table 1: Distribution of patients according to USG maturity.

\begin{tabular}{|ll|}
\hline Maturity in weeks & No. of patients (in \%) \\
\hline $\mathbf{1 5 - 2 0}$ & 10 \\
\hline $\mathbf{2 1 - 2 5}$ & 26 \\
\hline $\mathbf{2 6 - 3 0}$ & 49 \\
\hline $\mathbf{3 1 - 3 4}$ & 15 \\
\hline
\end{tabular}

Table 2: Average Hb level in different groups.

\begin{tabular}{|ll|}
\hline Maturity in weeks & Average $\mathbf{H b}$ \\
\hline $\mathbf{1 5 - 2 0}$ & 6.3 \\
\hline $\mathbf{2 1 - 2 5}$ & 7.33 \\
\hline $\mathbf{2 6 - 3 0}$ & 7.4 \\
\hline $\mathbf{3 1 - 3 4}$ & 7.1 \\
\hline
\end{tabular}

Table 3: Average increase in $\mathrm{Hb}$ level.

\begin{tabular}{|ll|}
\hline Maturity in weeks & $\begin{array}{l}\text { A verage increase in Hb level (in } \\
\text { gm.) }\end{array}$ \\
\hline $\mathbf{1 5 - 2 0}$ & 2.6 \\
\hline $\mathbf{2 1 - 2 5}$ & 1.8 \\
\hline $\mathbf{2 6 - 3 0}$ & 1.8 \\
\hline $\mathbf{3 1 - 3 4}$ & 2.3 \\
\hline
\end{tabular}

Table 4: Side effects.

\begin{tabular}{|ll|}
\hline $\begin{array}{l}\text { Side effect } \\
\text { Mild (nausea, vomiting, } \\
\text { constipation) }\end{array}$ & 8 \\
\hline $\begin{array}{l}\text { Moderate (diarrhoea, } \\
\text { itching) }\end{array}$ & 6 \\
\hline Severe (bronchospasm) & 0 \\
\hline Discontinuation of therapy & 0 \\
\hline
\end{tabular}

\section{DISCUSSION}

The fetus and placenta require about total $500 \mathrm{mg}$ of iron and a similar amount is needed for red cell increment. An average postpartum blood loss and lactation for six months each accounts for about $180 \mathrm{mg}$. From total of $1360 \mathrm{mg}, 350 \mathrm{mg}$ may be subtracted (saved as a result of amenorrhea) to give an actual extra demand for about $1000 \mathrm{mg}$. This is unlikely to be provided by dietary iron but may be mobilized from full iron stores (about 1000 $\mathrm{mg}$ ). It is the state of stores that largely determine whether or not a pregnant woman becomes anemic. The smaller her stores, the earlier the anemia occurs.
Table 5: Change in lab values in iron deficiency anemia.

\begin{tabular}{|ll|}
\hline Change & Parameter \\
\hline Decrease & Ferritin, hemoglobin, MCV \\
\hline Increase & TIBC, Transferrin, RDW \\
\hline
\end{tabular}

Treatment of IDA has included oral iron, intramuscular iron, iron dextran, ISC, recombinant erythropoietin and blood transfusion. However, most of these have their disadvantages. Even patients who respond well to oral iron therapy require a long time (months) to reach target $\mathrm{Hb}$ compared with weeks required in case of treatment with ISC. The compliance is always a problem and to improve this, even iron-rich natural mineral water has been tried to treat IDA in pregnant women.

The use of intramuscular iron preparations in IDA is discouraged because of pain, irregular absorption and staining. Iron preparations in higher/excess dose following intravenous administration might cause liver necrosis, renal, suprarenal and pulmonary damage. The slow release of elementary iron from the complex can lead to the mild allergic. The minimal undesirable effect observed in the treated patients can be easily managed. In addition, the tissue accumulation of iron-sucrose in parenchymatous organs is much lower as compared to iron- dextran/ sorbitol complex. Iron sucrose complex gets rapidly incorporated into the bone marrow for erythropoiesis in comparison to other iron complexes. ${ }^{13}$ ${ }^{15,16}$ Unlike intravenous iron- dextran/sorbitol complex, anaphylactic reactions are virtually unknown with iron sucrose. $^{14,15}$

In present study, only 8 of the 100 patients had mild side effects and none had anaphylaxis, thus showing the safety of the drug in the pregnant women. Side effects were limited in the present study because the total dose of ISC was administered at intervals and it was given in diluted form and slowly. Thus our study showed that iron sucrose complex can be used in the pregnant patients with iron deficiency anemia. Intravenous iron is superior to oral iron with respect to faster increase in $\mathrm{Hb}$ and faster replenishment of body iron stores. ${ }^{15}$ Also, it reduces the need of blood transfusions. ${ }^{17}$

Table 6: Effects of Iron therapy in pregnant women.

\begin{tabular}{|llll|}
\hline Type & Oral iron & $\begin{array}{l}\text { I.m.iron } \\
\text { (iron } \\
\text { dextran) }\end{array}$ & Iron sucrose \\
\hline $\begin{array}{l}\text { Duration of } \\
\text { therapy }\end{array}$ & Long & Short & Short \\
\hline Compliance & Less & Less & More \\
\hline Side effects & $\begin{array}{l}\text { More } \\
\text { (constipation, } \\
\text { staining, } \\
\text { vomiting) }\end{array}$ & $\begin{array}{l}\text { More } \\
\text { (staining, } \\
\text { itching, } \\
\text { pain) }\end{array}$ & $\begin{array}{l}\text { Less (nausea, } \\
\text { vomiting, } \\
\text { constipation, } \\
\text { diarrhoea, } \\
\text { itching) }\end{array}$ \\
\hline
\end{tabular}




\section{CONCLUSIONS}

Out of 100 patients maximum number of patients were between 26-30 weeks maturity. In all of them $\mathrm{Hb}$ level improved by an average of 1.8 grams.

In our study we found maximum improvement in $\mathrm{Hb}$ level during early second trimester (15-20 weeks). Hb level has not increased up to the targeted level, but it has improved by average 2.1 Grams within a short duration (4 weeks).

Moreover only $14 \%$ pts suffered from minor side effects. This study showed significant improvement of $\mathrm{Hb}$ and iron stores in pregnant women given calculated dose of ISC infusion. It was safe and well tolerated. In our country with frequent IDA found in pregnancy, this type of treatment may be helpful in management of these patients.

\section{Funding: No funding sources}

Conflict of interest: None declared

Ethical approval: The study was approved by the Institutional Ethics Committee

\section{REFERENCES}

1. http://www.merriam-webster.com/dictionary/anemia.

2. Dutta DC. Anaemia in pregnancy. In: Text book of obstetrics including perinatology \& contraception. 6th ed. Calcutta, India:New Central Book Agency (P) Ltd.; 2004: 262-267.

3. Ezzati M, Lopus AD, Dogers A, Vander HS, Murray C. Selected major risk factors and global and regional burden of disease. Lancet. 2002;360:134760.

4. Toteja GS, Singh P, Dhillon BS, Saxena BN, Ahmed FU, Singh RP, et al. Prevalence of anemia among pregnant women and adolescent girls in 16 districts of India. Food Nutr Bull. 2006;27:311-5.

5. Kalaivani K. Prevalence \& consequences of anaemia in Pregnancy. Indian J Med Res. 2009;130: 627-33.

6. Planning Commission. Government of India. Tenth Five-5. Year Plan 2002-2007. Sectoral Policies and Programmes. Nutrition. Government of India, New Delhi; 2002. Available from: Planning commission.nic.in/plans/planrel/fiveryr/10th/ 10defaultchap.html. Accessed 12 December, 2012.
7. DLHS on RCH. Nutritional status of children and prevalence of anaemia among children, adolescent girls and pregnant women 2002-2004. Available at: http://www.rchindia.org/nr_india.htm 2006. Accessed 24 September 2008.

8. Toteja GS, Singh P. In: Micronutrient profile of Indian population. New Delhi: ICMR; 2004.

9. Milman N, Bergholt T, Byg K, Erikson L, Graudal $\mathrm{N}$. Iron status and iron balance during pregnancy, a critical reappraisal of iron supplementation. Acta obstet gynaecol Scand. 1999;78:749-57.

10. Mahomed K. Iron and folate supplementation in pregnancy. In the Cochrane library; Oxford update. 2002.

11. Momen AK, Meshari A, Nuaim L, Saddique A, Abotalib Z, Khashogji $\mathrm{T}$, et al. Intravenous iron sucrose in the treatment of iron deficiency anemia during pregnancy. Reprod boil.1996;69:121-4.

12. Bayoumeu F, Subiran-Buisset C, Baka NE, Legagneur H, Monnier-Barbarino P, Laxenaire MC. Iron therapy in iron deficiency anemia in pregnancy: Intravenous route versus oral route. Am J Obstet Gynecol. 2002;186(3):518-22.

13. Bhandal N, Russel R. Intravenous versus oral iron therapy in postpartum anemia. BJOC. 2006;113:1248-52.

14. Bailie G, Clark J, Lane CE, Lane PL. Hypersensitivity reactions and deaths associated with intravenous iron preparations. Nephrol Dial transplant. 2005:20:1443-49.

15. Bashiri A, Burstein E, Sheiner E, Mazor M. Anaemia during Pregnancy and treatment with intravenous iron: review of the literature. Eur J Obstet Gynecol Reprod Biol. 2003;110:2-7.

16. Krafft A, Perewusnyk G, Hänseler E, Quack K, Huch $\mathrm{R}$, Breymann C. Effect of postpartum iron supplementation on red cell and iron parameters in nonanaemic iron deficient women: a randomized placebo-controlled study. BJOG. 2005;112:445-50.

17. Hallak M, Sharon A, Duikman R, Auslender R, Abramovici. Supplementing iron intravenously in pregnancy. A way to avoid blood transfusions. J Reprod Med. 1997;42:99-103.

Cite this article as: Modh SV, Deliwala KJ, Shah PT, Patel RV. Role of iron sucrose infusion in correction of iron deficiency anemia during pregnancy. Int J Reprod Contracept Obstet Gynecol 2015;4:1940-3. 